\title{
IIES
}

\section{DOES WeLFARE REFORM AFFECT FERTILITY? EVIDENCE FROM THE UK}

\author{
Mike Brewer \\ Anita Ratcliffe \\ Sarah Smith
}




\title{
Does welfare reform affect fertility?
}

\section{Evidence from the UK}

\author{
Mike Brewer \\ (Institute for Fiscal Studies) \\ Anita Ratcliffe \\ (Centre for Market and Public Organisation, University of Bristol) \\ Sarah Smith ${ }^{1}$ \\ (CMPO, University of Bristol and IFS)
}

\section{Acknowledgements}

This research was funded by the ESRC under its programme, Understanding Population Trends and Processes (RES-163-25-0018), and through the Centre for Microeconomic Analysis of Public Policy at IFS. Material from the Family Expenditure Survey (FES), the Family Resources Survey (FRS) and the General Household Survey (GHS) was made available by the Office for National Statistics (ONS) through the UK Data Archive and has been used by permission of the Controller of HMSO. The authors would like to thank Richard Blundell, Hilary Hoynes and Karl Scholtz, as well as seminar participants at CMPO, IFS, ONS and the Ministry of Social Development, New Zealand for helpful comments and suggestions.

\footnotetext{
${ }^{1}$ Corresponding author: sarah.smith@bristol.ac.uk
} 


\section{Abstract}

In 1999 the UK government made major reforms to the system of child-contingent benefits, including the introduction of Working Families' Tax Credit and an increase in means-tested Income Support for families with children. Between 1999-2003 government spending per-child on these benefits rose by 50 per cent in real terms, a change that was unprecedented over a thirty year period. This paper examines whether there was a response in childbearing. To identify the effect of the reforms, we exploit the fact that the spending increases were targeted at low-income households and we use the (exogenously determined) education of the woman and her partner to define treatment and control groups. We argue that the reforms are most likely to have a positive fertility effect for women in couples and show that this is the case. We find that there was an increase in births (by around 15 per cent) among the group affected by the reforms.

Key words : Welfare reform; Fertility; Working Families Tax Credit

JEL Classification: J13, J18, H53 


\section{Executive Summary}

In 1999 the UK government made major reforms to the system of child-contingent benefits, including the introduction of Working Families' Tax Credit and an increase in means-tested Income Support for families with children. Between 1999-2003 government spending per-child on these benefits rose by 50 per cent in real terms, a change that was unprecedented over a thirty year period. This paper examines whether there was a response in childbearing. To identify the effect of the reforms, we exploit the fact that the spending increases were targeted at low-income households and we use the (exogenously determined) education of the woman and her partner to define treatment and control groups. We argue that the reforms are most likely to have a positive fertility effect for women in couples and show that this is the case. We find that there was an increase in births (by around 15 per cent) among the group affected by the reforms. 


\section{$1 \quad$ Introduction}

This paper presents new evidence on the effect of welfare on fertility from the UK, focusing on a set of reforms to benefits for families with children introduced in 1999 . The Working Families' Tax Credit (WFTC), similar in design to the US Earned Income Tax Credit (EITC), increased the generosity of benefits for households with children where at least one parent worked 16 hours a week or more, ${ }^{2}$ while the generosity of means-tested Income Support (IS) payments to workless households with children also increased.

The UK makes a good case study because of the sheer scale of the reforms. Between 1999 and 2003, government spending per child on child-contingent cash transfers, payable tax credits and traditional tax allowances increased by 50 per cent in real terms, a change that was unprecedented over the previous thirty year period (Adam and Brewer, 2004). Most of the additional spending was targeted at low-income households. For the poorest one-fifth of couples with children, the changes increased cash benefits received for the first child by an amount equivalent to ten per cent of net household income. Since the main aims of the reforms were to improve work incentives (in the case of WFTC) and to reduce child poverty, there was no pronatalist intention and therefore little concern about policy endogeneity in examining the effect of the reform on fertility (see Besley and Case, 2000).

The employment effects of WFTC have been extensively analysed (see inter alia Gregg and Harkness, 2003, Blundell et al, 2005, Brewer et al, 2006, Francesconi and van der Klauuw, 2007, Leigh, 2007 and Gregg et al, 2009). Similar to the US studies

2 The reforms have been extensively documented elsewhere. For further details, see Brewer et al (2006), Francesconi and van der Klaauw (2007), Gregg and Harkness (2003) and Leigh (2007). 
of EITC (see Eissa and Leibman, 1996, and Eissa and Hoynes, 2004), these studies find a significant increase in employment among lone parents, but little overall effect on the employment of women in couples. There has been far less analysis of the impact of the UK reforms on fertility although this is an important, if possibly unintended, consequence of the reforms.

The only previous study of WFTC to consider fertility, Francesconi and van der Klauuw (2007), focused on lone mothers and found a (statistically insignificant) reduction in the probability of lone mothers having another child after the reforms ${ }^{3}$. However, as we argue below, the fertility incentives of the reforms for this group are ambiguous because the improved work incentives offered by WFTC could cause a reduction in fertility by raising the opportunity cost of an additional child. In our analysis, we focus on couples where the likely positive fertility effects are stronger.

Much of the existing evidence on the effect of welfare reform on fertility comes from the US where studies have typically exploited variation in program generosity and timing of implementation across states to identify an effect. In general, the US evidence finds that more generous welfare is associated with increased births (see Moffitt, 1998), although the results are sensitive to specification.

Since the UK reforms were nation-wide, we cannot follow the US studies in identifying the policy effect from variation across state and time. Instead, we exploit the fact that the reforms were targeted at low-income households and adopt the commonly- used difference-in-difference approach (see Angrist and Krueger, 1999).

\footnotetext{
${ }^{3}$ Ohinata (2008) uses the British Household Panel Survey to look at the effect of WFTC on fertility using a difference in differences approach. She conditions on pre-reform household income, in effect selecting heavily on pre-reform fertility.
} 
We look at the change in fertility before and after the reform for couples who were affected by the reform and use the change in fertility over the same period for couples unaffected by the reform to control for other (unobservable) time-varying effects. While this methodology cannot precisely disentangle individual policy effects, it can yield powerful and straightforward evidence on behavioural impacts (Ellwood, 1999). Because household income is likely to be affected by the reform, we use the education of the woman (and her partner) to define treatment and control groups.

The structure of the rest of the paper is as follows. The following section summarizes the previous literature in this area. Section 3 describes the UK reforms in further detail, and section 4 discusses the possible effect of the reforms on the incentives to have children. Sections 5 and 6 describe our empirical strategy and the data we use. Section 7 presents the results of regression analysis and section 8 offers some conclusions.

\section{Previous research}

According to a basic economic model of fertility (see Becker, 1991), more generous government support for children would tend to raise the desired number of children through both a positive income effect ${ }^{4}$ and a positive own price effect. There is a large US literature that tries to test this prediction with regard to welfare programs, much of it focusing on Aid to Families with Dependent Children (AFDC) (see Moffit, 1998, for an overview). Identification in studies of AFDC typically relies on variation in generosity across states and, although there is clearly a positive statistically

4 Alternatively, it has been argued that higher income is associated with demand for increased quality of children, implying a possible reduction in quantity demanded. 
significant correlation between welfare generosity and fertility, the results are sensitive to methodology and in particular, the inclusion of state fixed effects and trends (see Hoynes, 1997).

Of particular relevance to the UK 1999 reforms, a recent paper by Baughman and Dickert-Conlin (2003) looks at the effect of EITC on fertility. Focusing on first births and on women with less than college education, who are likely to be more affected by the reforms, they exploit variation in state EITC payments to identify an effect. They control for state fixed effects and time-varying policy and economic variables, but not state trends. Overall, they find that more generous EITC benefits have a negative effect on first births, although this is statistically insignificant. But they find a positive effect for married women and a larger effect for non-whites. In section 4 below we argue that positive fertility effects are more likely for women in couples and we focus on this group in our analysis, exploiting the fact that around half of recipient WFTC families are couples.

A number of other papers provide evidence that total fertility is responsive to government policy. Whittington et al (1990) use time series data from 1913 to 1984 to show that changes in the personal tax exemption for dependents in the US had a significant effect on the number of children born, with an implied elasticity of between 0.127 and 0.248 , while Whittington (1992) finds the same relationship using micro-data from the Panel Survey of Income Dynamics, with an estimated elasticity in the range $0.23-1.31$. For the UK, Ermisch (1988) finds that the magnitude of (universal) child benefit payments has an effect both on timing of entry into motherhood and on family size through third and fourth births. The simulated effect of doubling the real value of child benefit on family size is of similar (absolute) 
magnitude to the effect of doubling house prices.

A number of studies have looked at the effect of explicitly pro-natalist policies. Laroque and Salanie (2005) examined the effect of the Allocation Parentale d'Education (APE) introduced in France in 1994. In a discrete choice framework, they relate employment and fertility choices to the financial incentives implied by the tax and benefit system, and they find evidence of a small effect of the APE on childbearing, higher for first births, in spite of the fact that the benefit was paid in the event of higher order births; Laroque and Salanie (2008) generalise this and find evidence that first and third births in France are responsive to financial incentives. Milligan (2005) studied the effect of the Allowance for Newborn Children (ANC) introduced in Quebec in 1998, which paid 500 Canadian dollars for the first birth, $\$ 1,000$ for a second birth (split into two annual payments) and up to $\$ 8,000$ for a third birth (split into twenty quarterly payments). Exploiting the fact that the reform was introduced in Quebec and not in the rest of Canada, he estimated that the policy raised fertility by $12 \%$ in the case of first births and $25 \%$ in the case of third and subsequent births. He estimated that a $\$$ Can 1,000 increase in government support in the first year would increase the probability of having a child by $16.9 \%$. Perhaps surpris ingly, he found a bigger effect for higher income families.

Finally, a closely related literature has examined whether tax and transfer policy can affect the timing of births (these studies have typically assumed the quantity of births is unaffected). Kureishi and Wakabayashi (2008) and Dickert-Conlin and Chandra (1999) show that the operation of child tax deductions can encourage families to have children born towards the end of the fiscal year, rather than at the start (in Japan and the US respectively). Gans and Leigh (2006) show that the high-profile announcement, 
seven weeks in advance, of a AUS $\$ 3000$ bonus to babies born in Australia after July 12004 led to the situation where "on July 1 2004, more Australian children were born than on any other single date in the past thirty years".

\section{$3 \quad$ The reforms to child-contingent cash benefits in the UK}

Our focus in this paper is on a set of reforms in the UK that increased the generosity of government support to families with children that was initiated by the incoming Labour government in 1997 and introduced in 1999. Drawing extensively on the experience of welfare-to-work programs in North America, the Working Families' Tax Credit (WFTC) was introduced in October 1999 to provide improved work incentives for families with children, together with a number of additional programs, such as the New Deal for Lone Parents, offering training and other help with finding a job. Alongside this, however, the government also increased the generosity of meanstested income support payments to families with children. In this section we describe first the WFTC reform, and then the contemporaneous changes to welfare benefits and income tax, before finally analysing how the combined package of reforms affected the incomes of families with children. ${ }^{5}$

WFTC in fact represented a dramatic expansion and rebranding of an existing, small, in-work cash support program known as Family Credit (FC). Both WFTC and FC paid money to recipients working for at least 16 hours per week, tapered away with household ${ }^{6}$ earnings (plus some other forms of income) above a threshold. But WFTC was more generous in five ways: credits were higher, particularly for those

\footnotetext{
5 This discussion draws on Brewer and Browne (2006) and Brewer et al (2006). We do not describe the further set of reforms that took place after April 2003 : for further details see Brewer (2003). 6 The assessment was made on the basis of the couple's joint earnings even in the case of cohabiting couples.
} 
with younger children; families could earn more before the credit began to be withdrawn; the rate at which the credit was withdrawn was lower; support for formal childcare was more generous; and WFTC excluded child maintenance payments from its definition of income. Figure 1 (from Brewer, 2001) compares the WFTC schedule with that of the US equivalent, EITC, for the fiscal year 2000. It shows, compared with EITC, the absence of a phase-in portion for WFTC, the greater generosity of WFTC (at PPP rates) and the steeper phase-out of WFTC.

Take-up of the new programme increased quite dramatically. The number of households with children in receipt of credits rose from 786,000 in August 1999, just before WFTC was introduced, to $1,327,000$ in November 2002. This compares to a total of $6.98 \mathrm{~m}$ families claiming (universal) child benefit in November 2002. Just under one-half of WFTC recipients $(46 \%)$ were in a couple. ${ }^{7}$ 


\section{Figure 1}

\section{WFTC and EITC schedules compared, 2000}

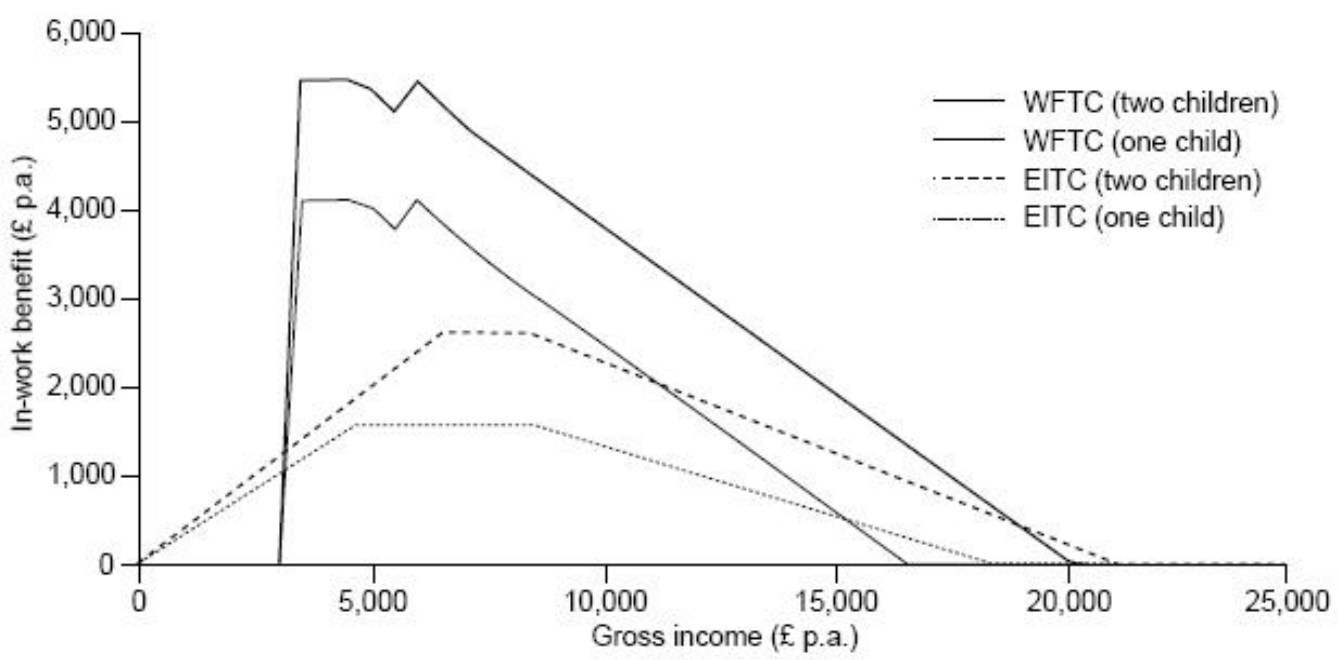

Notes: $£ 1=\$ 1.50$. Assumes 2000 tax system in US. Assumes 2000 tax system in UK plus children's tax credit. Assumes two WFTC awards a year and minimum-wage work in UK, so eligible for 30-hour credit at gross annual income of $£ 5,772(52 \times 30 \times £ 3.70)$.

The introduction of WFTC was not the whole story; other income tax allowances and transfer programs were available to families with children during the period under consideration, and most saw some change at the same time as WFTC was introduced. Child benefit, a cash benefit available to all families with children regardless of income, saw a small increase in the amount paid in respect of the first child; welfare benefits for families on a low income and working fewer than 16 hours a week saw considerable increases in the amounts paid in respect of children, and a small nonrefundable income tax credit for parents was introduced in 2001.

Overall, this combined set of changes amounted to a huge increase in the total package of child-contingent cash support from the state, whether provided through cash benefits, in-work tax credits or income tax deductions: government spending on all child-contingent support programs rose by 50 per cent in real terms between 1999 and 2003 (Adam and Brewer, 2004) a change that was unprecedented over a thirty year period. But the change was far more important for low-income families than 
better-off families, because the rise in spending was dominated by the means-tested WFTC and the higher means-tested out-of-work benefits for families with children.

Figure 2 shows the change over this period in income from child-contingent benefits as a proportion of (pre-reform) net household income, by deciles of income (adjusted for household composition), for couples with one child and for couples with two or more children. This makes it clear that the introduction of WFTC was the most important single element in terms of raising the incomes of families with children. It also highlights how the effects of the changes were concentrated among poorer households. For those in the bottom fifth of the income distribution, the rise in childcontingent support meant increases in net income of around 10 per cent for those with one child, and over 12 per cent for those with two or more children. 
Figure 2

Increase in child-contingent benefits, 1998 - 2002

Couples, one child

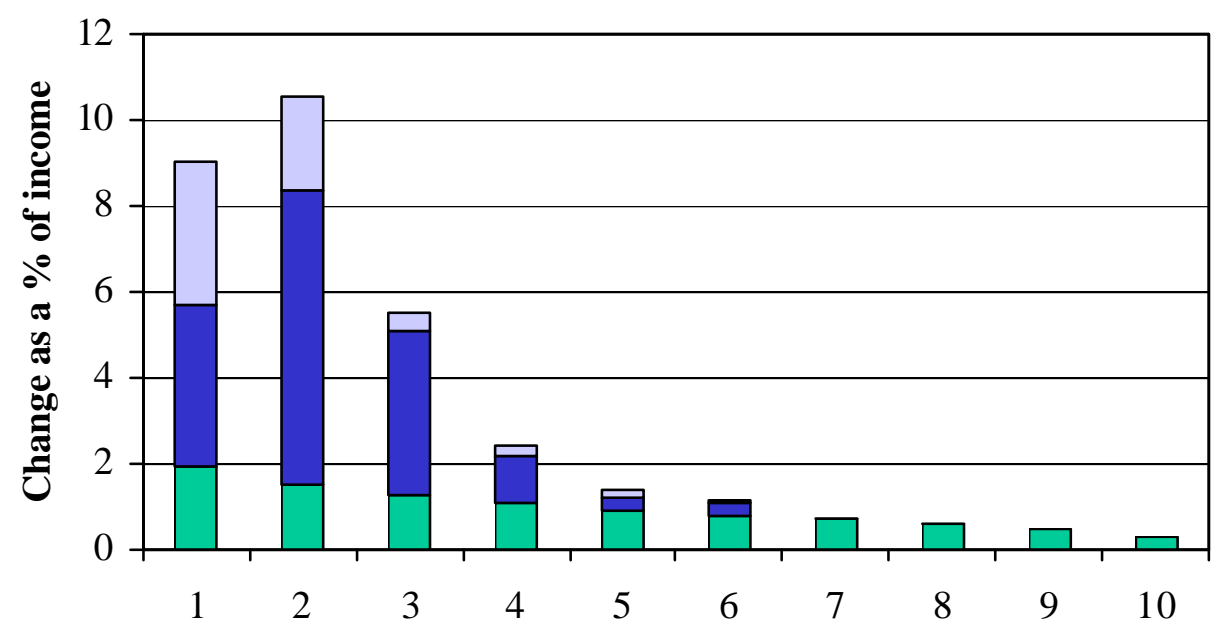

Decile of income, households with children

$\square$ Universal child benefit $\square$ Tax credits $\square$ Means-tested benefits

\section{Couples, two children}

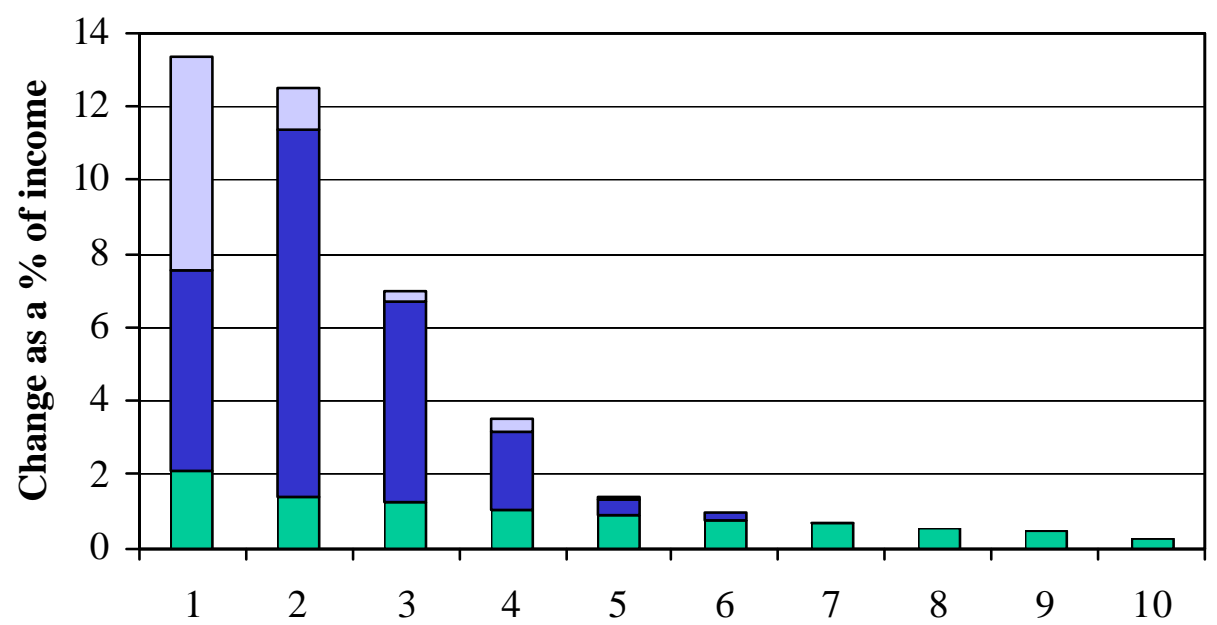

Decile of income, households with children

$\square$ Universal child benefit $\square$ Tax credits $\square$ Means-tested benefits

Authors' calculations based on estimated entitlements calculated using TAXBEN, the IFS' tax and benefit calculator, based on data from the Family Resources Survey 2002/3. 


\section{The impact on fertility}

Considering a simple economic model of fertility, there are a number of possible channels through which the package of reforms outlined above might impact on the desired number of children:

- Families eligible for WFTC or income support will experience a positive income effect which, if children are a normal good, will tend to increase demand.

- Increased means-tested government support is likely to reduce income volatility $^{8}$ and this will also tend to increase the demand for children (see Fraser, 2001).

- The increase in child-contingent benefits ${ }^{9}$ will lower the own price of an additional child for eligible women, increasing demand.

- For women on the taper of the WFTC schedule, the fall in net wages will reduce the opportunity cost of an additional child and this will also tend to increase the demand for children.

- But, for women who are induced to move into, or increase, employment by the introduction of WFTC (potentially anyone below the minimum threshold shown in Figure 1), the opportunity cost of an additional child will be higher and this will tend to reduce the demand for children.

\footnotetext{
8 Gregg et al (2008) show that an important effect of WFTC was to mitigate the negative impact of moving into lone parenthood on employment and income.

9 Including the increase in support with payments for childcare
} 
In summary, the reforms will have positive impacts on fertility through income, insurance and price effects, but an ambiguous impact through the employment (or opportunity cost) effect. Crucially, this employment effect is likely to vary between different sorts of (potential) mothers.

For lone mothers whose eligibility for WFTC is assessed at the individual level, the labor market participation effects of WFTC are una mbiguously positive. The credit provides an incentive for non-working lone mothers to move into work. Those working more than 16 hours prior to the reform may have an incentive to reduce their hours both because their incomes are higher and because of the negative substitution effect created by the taper, but the 16-hour condition in WFTC ensures that labor supply does not fall to zero. All of the studies that look at the effect of WFTC on participation, summarized in Table 1, find a positive and significant effect of WFTC on the employment of this group (see also Brewer and Browne, 2006, for a review and careful comparison of these studies).

For women in couples who are the secondary earner (as is typically the case), WFTC may actually reduce participation. WFTC has the same income and substitution effects as for lone mothers, but women in couples may reduce her hours below 16 or leave the labor market altogether if the family will continue to be eligible for WFTC on the basis of her partner's participation. Fewer studies have looked at the impact of WFTC on women in couples, but most of those that do, summarized in Table 1, 
suggest a small reduction in participation among women with employed partners, and

a small positive effect for (the small group of) women with unemployed partners. ${ }^{10}$

Table 1

The employment effects of WFTC - summary of evidence

\begin{tabular}{|c|c|c|c|}
\hline Study & Methodology & Lone parents & Couples \\
\hline $\begin{array}{l}\text { Blundell et al } \\
(2000)\end{array}$ & $\begin{array}{l}\text { Use estimates from structural } \\
\text { model to simulate likely } \\
\text { response; looks only at initial } \\
\text { (Oct 99) levels of WFTC }\end{array}$ & $\begin{array}{l}2.2 \mathrm{ppt} \text { increase in } \\
\text { employment of lone } \\
\text { mothers }\end{array}$ & $\begin{array}{l}0.6 \text { ppt reduction in } \\
\text { employment for } \\
\text { women with employed } \\
\text { partners }\end{array}$ \\
\hline $\begin{array}{l}\text { Gregg and } \\
\text { Harkness } \\
(2003)\end{array}$ & $\begin{array}{l}\text { Apply DD methodology (with } \\
\text { propensity score matching) to } \\
\text { Household Labour Force Survey } \\
\text { data } 1992-2002\end{array}$ & $\begin{array}{l}5 \text { ppt increase in } \\
\text { employment of lone } \\
\text { parents }\end{array}$ & \\
\hline $\begin{array}{l}\text { Blundell et al } \\
(2005)\end{array}$ & $\begin{array}{l}\text { Estimate DD model using } \\
\text { Labour Force Survey data } 1996 \\
-2002\end{array}$ & $\begin{array}{l}3.6 \text { ppt increase in } \\
\text { employment of lone } \\
\text { mothers working } 16+ \\
\text { hours a week }\end{array}$ & $\begin{array}{l}2.6 \text { ppt increase in } \\
\text { employment of women } \\
\text { with unemp loyed } \\
\text { partners; no effect for } \\
\text { women with employed } \\
\text { partners }\end{array}$ \\
\hline $\begin{array}{l}\text { Brewer et al } \\
(2006)\end{array}$ & $\begin{array}{l}\text { Estimate structural model using } \\
\text { Family Resources Data } 1995 \text { - } \\
2003\end{array}$ & $\begin{array}{l}5.1 \text { ppt increase in } \\
\text { employment of lone } \\
\text { mothers }\end{array}$ & $\begin{array}{l}0.6 \text { ppt reduction in } \\
\text { employment for } \\
\text { women with employed } \\
\text { partners, } 0.1 \mathrm{ppt} \\
\text { increase for women } \\
\text { with non-employed } \\
\text { partners, } 0.6 \mathrm{ppt} \\
\text { reduction for all } \\
\text { women. }\end{array}$ \\
\hline $\begin{array}{l}\text { Francesconi } \\
\text { and van der } \\
\text { Klauuw } \\
(2007)\end{array}$ & $\begin{array}{l}\text { Estimate DD model using British } \\
\text { Household Panel Survey data } \\
1991-2002\end{array}$ & $\begin{array}{l}7 \text { ppt increase in } \\
\text { employment of lone } \\
\text { mothers working } 16+ \\
\text { hours a week }\end{array}$ & \\
\hline Leigh (2007) & $\begin{array}{l}\text { DD model using panel data from } \\
\text { the Quarterly Labour Force } \\
\text { Survey } 1999-2000\end{array}$ & $\begin{array}{l}1 \mathrm{ppt} \text { increase in } \\
\text { employment among } \\
\text { lone parents }\end{array}$ & $\begin{array}{l}1 \mathrm{ppt} \text { increase in } \\
\text { employment among } \\
\text { women in couples }\end{array}$ \\
\hline
\end{tabular}

10 The reforms other than WFTC mentioned in section 3 would have had very small impacts on participation of mothers in couples, and would have worked in the same direction, ie to discourage labour market participation for women in couples. 
This suggests that the positive employment effect of WFTC (which would lead to reduced fertility) is less prevalent for women in couples than it is for lone mothers; it is therefore more likely that the reforms will have a positive effect on fertility for this group. We provide evidence of this below, consistent with the findings from the US for EITC (Dickert-Conlin and Baughman, 2005), and we focus on this group in our analysis.

\section{$5 \quad$ Empirical strategy}

We would like to measure the effect of the reforms on childbearing among women who are affected by the reform, i.e.:

$$
E\left(N_{l}-N_{l}^{\prime} \mid T=1\right)=E\left(N_{l} \mid T=1\right)-E\left(N_{l}^{\prime} \mid T=1\right)
$$

where $\mathrm{N}_{1}$ is the actual number of children within the group of women affected by the reform (the treatment group, $\mathrm{T}=1$ ) and $\mathrm{N}_{1}$ ' is the number of children they would have had in the absence of the reform.

Of course, $\mathrm{E}\left(\mathrm{N}_{1}{ }^{\prime} \mid \mathrm{T}=1\right)$ is not known since there is no way of knowing how many children the treatment group would have had in the absence of the reform. The difference-in-difference approach uses the change in fertility over the same period of a control group who were unaffected by the reform to proxy for the change that otherwise would have occurred within the treatment group in the absence of the reform. Applying this change to the initial fertility level of the treatment group gives an estimate of $\mathrm{E}\left(\mathrm{N}_{1}, \mid \mathrm{T}=1\right)$.

The DD approach therefore measures the following:

$$
\left[E\left(N_{l} \mid T=1\right)-E\left(N_{0} \mid T=1\right)\right]-\left[E\left(N_{l} \mid T=0\right)-E\left(N_{0} \mid T=0\right)\right]
$$

where $\mathrm{N}_{0}$ is the number of children prior to the reform and $\mathrm{T}=0$ contains the control 
group who are unaffected by the reform.

We exploit the fact that the reforms were targeted at low-income households to define treatment and control groups. However, while household incomes are likely to be strongly correlated with the reforms' impact, they are also likely to be endogenous and affected by impact of the reforms on both employment and fertility. Instead we use education as a time-invariant proxy for income to define treatment and control groups. In the short-term at least, we can be confident that education choices are unaffected by the reforms.

Our analysis focuses, first, on all women and, secondly, on women in couples for whom we can incorporate additional information on partner's education to get a tighter definition of treatment and control groups. In our all women sample, the treatment group includes women who left full-time education at the minimum school leaving age, ${ }^{11}$ while the control group is women who left full-time education aged 19 years or more. In our sample of women in couples, the treatment group includes women who both left full-time education at the minimum school leaving age and have a partner who left at this age. Similarly, the control group includes women who both left full-time education at $19+$ and who have a partner who left full-time education at this age.

Compared to using income or earnings, the potential disadvantage of using education is that it is less strongly correlated with the impact of the reform. There are some people with a (low) high level of education whose earnings nevertheless do (not) qualify them for tax credits or means-tested benefits. Table 2 illustrates the extent to which our education splits pick up the differential impact of the reforms across the

\footnotetext{
${ }^{11}$ The minimum school leaving age was raised from 14 to 15 from 1944 and from 15 to 16 from 1973.
} 
treatment and control groups. As expected, incorporating additional information on partner's education produces a clearer differentiation between treatment and control groups.

Table 2

\section{Receipt of child-contingent benefits}

\begin{tabular}{|c|c|c|c|c|}
\hline & \multicolumn{2}{|c|}{ Split by woman's education } & \multicolumn{2}{|c|}{$\begin{array}{l}\text { Split by education of } \\
\text { woman and partner }\end{array}$} \\
\hline & Treatment & Control & Treatment & Control \\
\hline & $\begin{array}{l}\text { Woman left school } \\
\text { at minimum school } \\
\text { leaving age }\end{array}$ & $\begin{array}{l}\text { Woman left FT } \\
\text { educ aged } 19+\end{array}$ & $\begin{array}{l}\text { Both woman and } \\
\text { partner left school } \\
\text { at minimum school } \\
\text { leaving age }\end{array}$ & $\begin{array}{c}\text { Both woman and } \\
\text { partner left FT educ } \\
\text { aged } 19+\end{array}$ \\
\hline \multicolumn{5}{|c|}{ Proportion entitled to child-related tax credits or means-tested benefits } \\
\hline $\begin{array}{l}\text { Before } \\
\text { After }\end{array}$ & $\begin{array}{r}.400 \\
.515\end{array}$ & $\begin{array}{l}.121 \\
.186\end{array}$ & $\begin{array}{l}.237 \\
.401\end{array}$ & $\begin{array}{r}.098 \\
.141 \\
\end{array}$ \\
\hline \multicolumn{5}{|c|}{ Mean weekly entitlement - tax credits, means-tested benefits and universal child benefit } \\
\hline Before & $£ 51.64$ & $£ 30.77$ & $£ 39.00$ & $£ 29.71$ \\
\hline After & $£ 69.74$ & $£ 39.90$ & $£ 56.76$ & $£ 37.27$ \\
\hline Difference & $£ 18.10(35.1 \%)$ & $£ 9.13(29.7 \%)$ & $£ 17.76(45.5 \%)$ & $£ 7.56(25.4 \%)$ \\
\hline
\end{tabular}

Source: Authors' calculations based on estimated entitlements calculated using TAXBEN, the IFS' tax and benefit calculator, based on data from the Family Resources Survey 2002/3.

Identifying the effect of the reform using a difference in difference approach relies crucially on successfully controlling for everything else that might affect the fertility of the treatment group after the reform. In our regression analysis we include a rich set of demographic controls, including age, education, numbers and ages of children in the household, region, housing tenure and ethnicity. In principle, the inclusion of the control group is intended to capture the effect of other (unobservable) timevarying factors. But the control group may differ to the treatment group, both in the level of their fertility (which the differencing takes care of) and, more problematically, in trends in their fertility. Smith and Ratcliffe (2008) show that the education gradient 
in fertility has been relatively stable across recent cohorts. However we explicitly allow for differential (non-linear) trends in the regression. We also include a number of macro variables which may affect fertility, including male and female wages, house prices and regional unemployment and allow their effects to vary by education.

As already noted, the DD methodology cannot precisely disentangle individual policy effects (such as separating the effect of WFTC from that of changes to income support). Our estimate is therefore of the combined effect of the set of reforms introduced in 1999. It will also include the effect of any other reforms introduced at the same time that affected the fertility of the treatment group (and not the control group). In fact, a number of changes were made to maternity rights and child-care provision that may have affected fertility, including extensions to maternity leave and increases in free nursery provision. ${ }^{12}$ In principle, all women were affected by these reforms, but in practice, the impact may have been greater for women in the low education group if they previously had less generous maternity provisions in their employment, and were less able to afford childcare. If so, then our DD estimate will also inc lude the differential effect of these other reforms. We would argue, however, that the effects of these reforms are likely to be small compared to the impact of WFTC and the changes to income support.

In principle, we would like to measure the effect of the reforms on the total number of children over the fertility lifetime of affected cohorts. This would include older cohorts, who are likely to have already started their family formation process at the time of the reform, as well as younger cohorts who make all their fertility decisions facing the post-reform financial incentives. In practice, we do not have sufficient 
number of years' data after the reform to look at completed fertility for affected cohorts. Also, even if the data were available, it would be hard to attribute changes in fertility across cohorts separated by several years to a discrete policy reform.

Instead, we define the variable of interest as the probability of having a birth during the previous year, and compare the changes in these birth probabilities before and after the reform for the treatment and control groups. This means that we cannot fully distinguish whether an observed effect is due to changes in the total number of births or changes in timing, although we attempt to do so by looking at the age at first birth.

A final issue relates to the definition of the "before" and "after" periods in determining the effect of the reform. WFTC was announced in March 1998 and introduced in October 1999. Assuming no announcement effects - as if the reform came as complete surprise in October 1999 - the reform would first have affected births from August 2000. We therefore include women interviewed between $1^{\text {st }}$ April 1995 and $30^{\text {th }}$ June 2000 in the "before" sample, ${ }^{13}$ and women interviewed between $1^{\text {st }}$ August 2001 and $31^{\text {st }}$ December 2003 in the "after" sample. ${ }^{14}$ For women interviewed between $1^{\text {st }}$ July 2000 and $31^{\text {st }}$ July 2001, the introduction of the reform (plus nine months) occurs in the middle of the twelve month period prior to their interview and so they are omitted from the analysis.

What if there is an effect arising from announcement? This could increase births in the immediate before period if women respond to the announcement of the reforms rather than (or as well as) their implementation. This is not implausible. The Labour government took office in 1997 promising big increases in financial support for low-

\footnotetext{
$13 \mathrm{We}$ choose end of June rather than end of July to allow for premature births

${ }^{\mathbf{1 4}}$ Further reforms we re made to the system of child -contingent benefits from this time.
} 
income families, and the reforms were announced in March 1998. So long as the promised increase in benefits is credible, then the loss arising from the gap between announcement and implementation would be relatively small compared to the expected increase in benefits over the child's lifetime. Alternatively, after announcement, women could decide to delay childbearing until after the reforms were implemented, which would tend to decrease births in the immediate before period (an effect similar to "Ashenfelter's dip", see Ashenfelter, 1978). In either case, failing to take account of a possible announcement effect would bias our estimate of the effect of the reforms. We therefore test the sensitivity of our results to possible announcement effects by trimming the before sample at $31^{\text {st }}$ December 1998 (nine months after the reform was announced).

\section{Data}

Our analysis pools data from successive waves of the Family Expenditure Survey (FES) from financial year 1990/01 until 2003/04 and the Family Resources Survey (FRS) from 1995/96 until 2003/04. Both are large repeated cross-section datasets collecting a wide range of socio-economic and demographic information on, respectively, over 7,000 and 20,000 households each year. The combined sample yields over 800 births each year, with interview dates spread roughly equally across the year. While potentially attractive as a panel, the British Household Panel Survey (used by Francesconi and van der Klauw, 2007) has fewer than 150 births a year. We focus on women aged 20-45; at younger ages, many women are still in full-time education, which means that our conditioning variable will not be exogenous. 
The FES and FRS do not explicitly collect information on births or women's fertility histories. But we derive the probability that a woman had a birth in the previous twelve months from children's date of birth ${ }^{15}$ and the date of interview after allocating all children in the household to their natural mothers on the basis of information on household composition. Using this approach(the so-called "own child method" see Murphy et al, 1993) we also determine the number and ages of the children in the household twelve months before interview. Birth probabilities estimated by this approach are potentially subject to measurement error due to infant mortality and household reconstitution. However, low rates of mortality, and the fact that the overwhelming majority of children stay with their natural mother in the event of family break-up, reduce the effect of these factors in practice. ${ }^{16}$

As a check on the validity of our data, we compare an estimate of annual total fertility ${ }^{17}$ derived from the FES/FRS with the official estimate of annual total fertility derived by the Office for National Statistics (ONS) from registration data. As shown in Figure 3 our estimate derived from FES/FRS data picks up the main trends in fertility over the period - declining fertility over much of the period, reversed from 2001. If anything, the upward trend is under-stated in the FES/FRS, although the downward trend is slightly over-stated. Our derived measure consistently lies below

\footnotetext{
${ }^{15}$ Where this is missing, we randomly allocate a date of birth given the age of the child and the date of interview. This is the case for all births in the FES sample and $16 \%$ of births in the FRS sample.

16 Another issue that affects information on the number and ages of existing children at the start of the twelve-month period (but not information on births during that period) is that older women may have had children who have now left home. We test the sensitivity of our results to restricting our sample to women aged 37 and under for whom this does not appear to be a problem. 17 This is measured as the total number of children a woman would have over her (reproductive) lifetime, if she experienced the age-specific birth rates in a particular year
} 
the official measure, which may reflect the narrower age range in our FES/FRS subsample.

Figure 3: Estimated annual birth rates

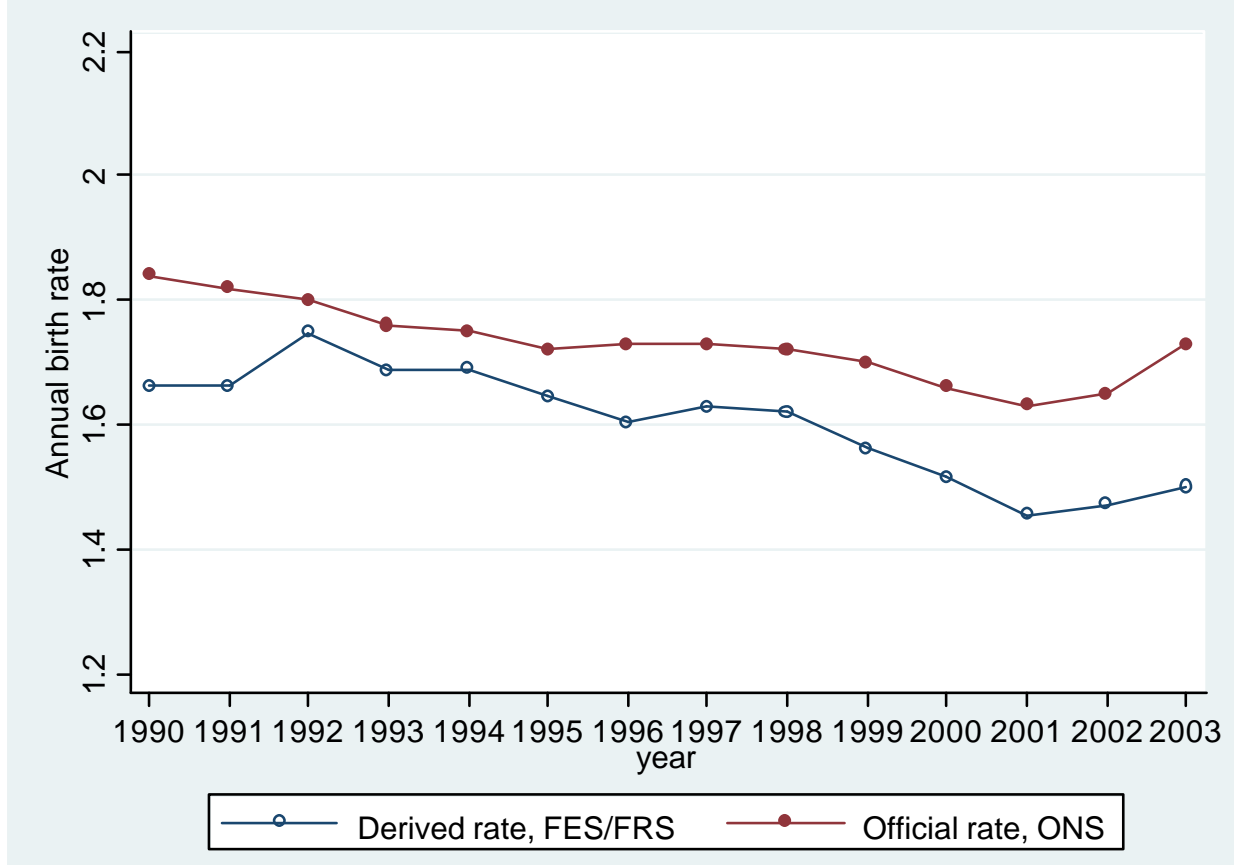

Figure 4 below shows the raw differences in birth probabilities between treatment and control groups each year from 1990/91 to 2003/04 (together with standard errors). These are based on a sample of 101,330 women aged 20-45, split between treatment and control on the basis of the woman's education (sample summary statistics are given in Table A.1 in the Appendix). We show the differentials separately for single women and women in (married or cohabiting) couples.

The raw data provide slight evidence of a relative increase in fertility among the treatment group in the post-reform period (from 1999/00) - more evident for women in couples than single women. It is clear that any increase among the treatment group in the post-reform period is not reflecting the continuation of a general upward trend. There was a decline in the raw differentials for women in couples, possibly due to 
differential changes in selection into partnership over the period (Smith and Ratcliffe, 2009). In our regression analysis we include controls for age, interacted with education, as well as differential (non-linear) trends.

\section{Figure 4}

\section{Raw differentials in births betwe en treatment and control groups, All women sample}

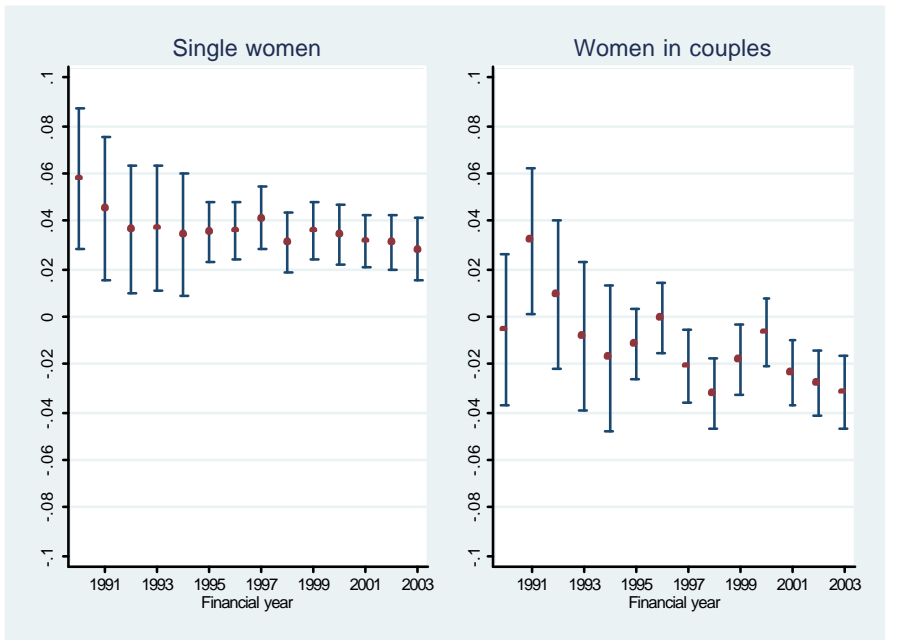

One particular issue of potential concern is if the reforms differentially affected partnership formation and separation. Unlike traditional means-tested benefits that typically create partnership penalties, the incentives associated with in-work tax credits are ambiguous since they support one-earner couples and may make lowearning males (financially) more attractive. Anderberg (2008) shows that the introduction of WFTC was associated with an increase in the number of couples who faced partnership bonuses, although this was almost entirely offset by the increase in means-tested benefits that occurred at the same time. Taken together, the available evidence suggests very little change in partnership following the reforms (see Gregg et al, 2009). There may have been a change in selection into couples on the basis of fertility intentions; our estimates will therefore include this effect. 


\section{$7 \quad$ Regression results}

The outcome of interest is a binary variable equal to one if the woman had a birth in the previous twelve months, and equal to zero otherwise (Birth). The basic difference-in-difference specification (1) includes a binary variable Low equal to one if the individual belongs to the low-education treatment group, a binary variable Post equal to one in the post-reform period and an interaction term Low $\times$ Post, which captures the difference in the change in birth probability after the reform for the treatment group (compared to the control group) - our estimate of the effect of the reform.

$$
\text { Birth }_{i t}=\alpha+\beta_{1}(\text { Low } \times \text { Post })_{i t}+\beta_{2} \text { Low }_{i t}+\beta_{3} \text { Post }_{i t}+X_{i t} \delta+u_{i t}
$$

$X_{i t}$ is a vector of characteristics which are assumed to affect fertility. These include a cubic in the woman's age (at the start of the twelve month period), interacted with education; the number of children in the household (at the start of the twelve month period), interacted with the woman's age and with the woman's age and education and with the age of the youngest child; region and housing tenure.

We estimate equation (1) using a linear probability model for ease of interpretation of the coefficients. ${ }^{18}$ Our preliminary results, reported in Table $3,{ }^{19}$ confirm that there is a bigger increase in births among women in couples than among single women.

When we define the treatment and control groups more tightly for the sample of women in couples using additional evidence on partner's education, ${ }^{20}$ the estimated

\footnotetext{
${ }^{18}$ The average estimated marginal effects from a probit regression are very similar and these results are available on request.

${ }^{19}$ A full set of coefficients is given in Table A.2 in the Appendix.

${ }^{20}$ Details on this sub-sample are reported in Table A.1 in the Appendix
} 
coefficient increases and becomes statistically significant at the 5 per cent level. The magnitude of the coefficient indicates a fairly large response to the reforms. The probability of birth among the treatment group in the pre-reform period was 0.089 , so a 1.3 percentage point rise would imply an increase of around 15 per cent.

\section{Table 3: Linear model, births}

Dependent variable: Birth in the last twelve months $(0 / 1)$

\begin{tabular}{|c|c|c|c|c|}
\hline \multirow{3}{*}{ Sample } & $(1)$ & $(2)$ & (3) & \multirow{3}{*}{$\begin{array}{l}\text { (4) } \\
\text { Women in couples } \\
\text { sample, split by } \\
\text { woman's and } \\
\text { partner's education }\end{array}$} \\
\hline & \multicolumn{3}{|c|}{$\begin{array}{c}\text { All women sample, split by woman's } \\
\text { education }\end{array}$} & \\
\hline & Pooled & $\begin{array}{c}\text { Women in } \\
\text { couples }\end{array}$ & $\begin{array}{c}\text { Single } \\
\text { women }\end{array}$ & \\
\hline \multirow[t]{2}{*}{ Low $\times$ Post } & .0045 & $.0083 *$ & .0021 & $.0133 * *$ \\
\hline & $(.0034)$ & $(.0050)$ & $(.0036)$ & $(.0064)$ \\
\hline $\mathrm{N}$ & 90523 & 58770 & 31753 & 40416 \\
\hline \multicolumn{5}{|c|}{$\begin{array}{l}\text { Notes to table: } \\
* * \text { indicates coefficient is statistically significant at the } 5 \% \text { level, * at the } 10 \% \text { level } \\
\text { All regressions include a dummy for the post-reform period and a full set of controls for age of mother, } \\
\text { education, age and number of children in the household, region and housing tenure. } \\
\text { As discussed in section } 5 \text {, we exclude women interviewed between } 20 \text { th June } 2000 \text { and } 1 \text { st August 2001; this } \\
\text { explains the reduced sample size. }\end{array}$} \\
\hline
\end{tabular}

Figure 5 plots the adjusted treatment-control differentials for each year (plus standard errors) once we have included the full set of demographic controls, together with the averages in the pre- and post reforms periods. It illustrates the increase in the postreform period, particularly compared to the years immediately before the reform, although to a level similar to the early 1990s. The biggest increase appears to be in the first year after the reform, 2000-01. There is some evidence of a dip in 1998-99 coinciding with the announcement of the reforms; our main result is robust to allowing for an announcement effect, as discussed at the end of section 5. 


\section{Figure 5}

\section{Adjusted birth differentials between treatment and control groups, Women in couples}

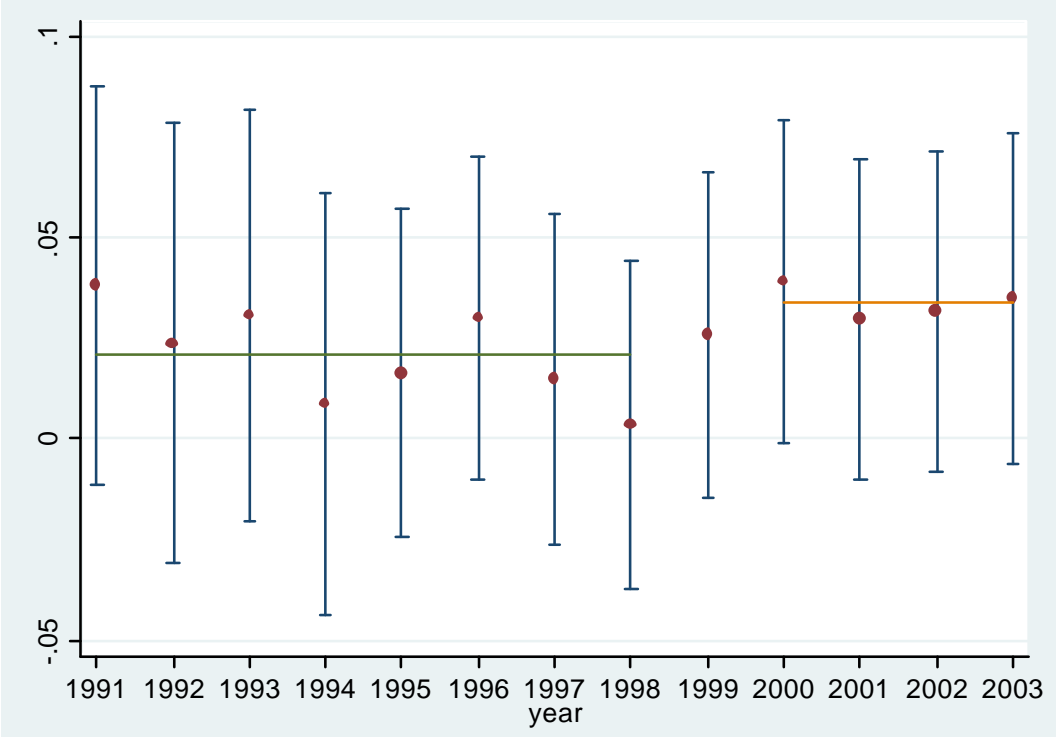

\section{Robustness checks}

In order to attribute the increase to the effect of the reforms, we need to control for any change in births that otherwise would have taken place among the treatment group in the absence of the reforms. Ethnicity may be an important omitted factor there has been an increase over time in the proportion of births to women born outside the UK, from $12.8 \%$ in 1996 to $21.9 \%$ in 2006 . Ethnicity information is only available from 1995 but running a regression over this shorter period and including ethnicity controls ${ }^{21}$ has almost no effect on the estimated treatment effect (Column (2) of Table 4).

21 The ethnicity information is fairly crude; we include indicators if the woman or her partner is Black, Chinese, Indian, Pakistani or Other (non-white). Many of the recent births to women born outside the 
We also test the robustness of our results to the inclusion of differential trends and macro factors. We allow for differential linear and quadratic trends and a number of macro controls, including the lag of log real house prices at the regional level and lagged male and female regional unemployment rates. We allow the effects of these variables to vary by education. We also include the (lag of the) $25^{\text {th }}$ and $75^{\text {th }}$ percentile of the female and male wage distributions, matched to the treatment and control groups respectively. ${ }^{22}$

The results from these specifications are included in Table 4. Column (1), panels (b) and (c) show the results of including differential linear and quadratic trends, while Column (3) adds the macro controls. The effect of these additional variables is to increase the standard error making it harder to identify a statistically significant effect, but the magnitude of the coefficient is reasonably robust.

UK are to recent white immigrants from the eight EU accession countries (including Poland, Czech Republic, Latvia, Lithuania, Estonia, Hungary, Slovakia and Slovenia). However, this wave of immigration occurred after the end of our period of analysis (beginning in May 2004).

${ }^{22}$ Wages, house prices and unemployment are identified by Ermisch (1988) as important determinants of fertility. 
Table 4: Linear model, births

Dependent variable: Birth in the last twelve months (0/1)

\begin{tabular}{|c|c|c|c|}
\hline Sample & $\begin{array}{c}(1) \\
\text { Women in couples, } \\
1990-2003\end{array}$ & $\begin{array}{c}\text { (2) } \\
\text { Women in couples, } \\
1995-2003\end{array}$ & $\begin{array}{c}\text { (3) } \\
\text { Women in couples, } \\
1990-2003\end{array}$ \\
\hline \multicolumn{4}{|l|}{ Panel (a) No trend } \\
\hline \multirow[t]{2}{*}{ Low $\times$ Post } & $.0133 * *$ & $.0129 * *$ & $.0174 *$ \\
\hline & $(.0064)$ & $(.0066)$ & $(.0098)$ \\
\hline Ethnicity indicators & No & Yes & No \\
\hline Macro variables & No & No & Yes \\
\hline \multicolumn{4}{|c|}{ Panel (b) Differential linear trend } \\
\hline Low $\times$ Post & $\begin{array}{l}.0115 \\
(.0102)\end{array}$ & $\begin{array}{l}.0116 \\
(.0136)\end{array}$ & $\begin{array}{c}.0264 * * \\
(.0129)\end{array}$ \\
\hline \multirow[t]{2}{*}{ Trend } & -.0003 & -.0007 & .0045 \\
\hline & $\begin{array}{l}(.0012) \\
.0003\end{array}$ & $\begin{array}{c}(.0020) \\
.0003\end{array}$ & $\begin{array}{l}(.0028) \\
-.0026\end{array}$ \\
\hline Diff trend & $(.0014)$ & $(.0024)$ & $(.0022)$ \\
\hline Ethnicity indicators & No & Yes & No \\
\hline Macro variables & No & No & Yes \\
\hline \multicolumn{4}{|c|}{ Panel (c) Differential non-linear trends } \\
\hline Low $\times$ Post & $\begin{array}{l}.0096 \\
(.0161)\end{array}$ & & $\begin{array}{l}.0087 \\
(.0178)\end{array}$ \\
\hline Trend & $\begin{array}{c}.0000 \\
(.0047)\end{array}$ & & $\begin{array}{c}.0102 \\
(.0075)\end{array}$ \\
\hline Trend squared & $\begin{array}{l}-.0000 \\
(.0003)\end{array}$ & & $\begin{array}{l}-.0003 \\
(.0004)\end{array}$ \\
\hline Diff trend & -.0004 & & $-.0134 *$ \\
\hline (Diff trend) squared & $\begin{array}{l}(.0053) \\
-.0000 \\
(.0003)\end{array}$ & & $\begin{array}{l}(.0079) \\
.0006 \\
(.0005)\end{array}$ \\
\hline Ethnicity indicators & No & Yes & No \\
\hline Macro variables & No & No & Yes \\
\hline $\mathrm{N}$ & 40416 & 34416 & 40465 \\
\hline \multicolumn{4}{|c|}{$\begin{array}{l}\text { Notes to table: } \\
* * \text { indicates coefficient is statistically significant at the } 5 \% \text { level, } * \text { at the } 10 \% \text { level }\end{array}$} \\
\hline \multicolumn{4}{|c|}{$\begin{array}{l}\text { All regressions include a dummy for the post-reform period and a full set of controls for age of mother, education, } \\
\text { age and number of children in the household, region and housing tenure. } \\
\text { Macro variables are lagged log real regional house prices and regional male and female unemployment rates and } \\
\text { male and female wage rates. } \\
\text { As discussed in section 5, we exclude women interviewed between } 20 \text { th June } 2000 \text { and 1st August 2001; this } \\
\text { explains the reduced sample size. }\end{array}$} \\
\hline
\end{tabular}

\section{Allowing for heterogeneous effects}

A number of previous studies have found fertility responses to vary by birth order.

Laroque and Salanie (2008), for example, find a stronger effect of the French

Allocation Parentale d'Education on first and third births. This may reflect a natural

break for women with very young children and/or strong preferences over family size. 
If so, the decision whether to have children (or at least when to begin having them)

may be more susceptible to financial incentives than the decision over how many to have, once childbearing has begun.

To explore this, we interact our indicator of the treatment effect with an indicator for whether or not the woman had children at the beginning of the twelve-month period, and with indicators for the number of children. The results, reported in Table 5, support previous findings of a stronger effect for first births, and also for third births. However, the differences by number of previous births are not statistically significant.

Table 5: Linear model, births

Sample: Women in couples aged 20-45, 1990-2003

Dependent variable: Birth in the last twelve months (0/1)

\begin{tabular}{lcc}
\hline & $(1)$ & $(2)$ \\
\hline Low $\times$ Post $\times$ No_children & $.0213^{* *}$ & $.0213^{* *}$ \\
Low $\times$ Post $\times$ Children & $(.0096)$ & $(.0096)$ \\
& $.0110^{*}$ & \\
Low $\times$ Post $\times$ One_child & $(.0064)$ & \\
& {$[0.2758]$} & .0081 \\
& & $(.0097)$ \\
Low $\times$ Post $\times$ Two_children & & {$[0.2807]$} \\
& & $.0140 * *$ \\
Low $\times$ Post $\times$ Threeplus_children & & $(.0068)$ \\
& & {$[0.4756]$} \\
$\mathrm{N}$ & & .0091 \\
& & $(.0077)$ \\
\end{tabular}

Notes to table:

** indicates coefficient is statistically significant at the $5 \%$ level, * at the $10 \%$ level. Figure in square brackets is p-value for the test that the effect is the same as for no_children.

Regressions include a dummy for the post-reform period and a full set of controls for age of mother, education, age and number of children in the household, region and housing tenure. 
Whether or not a woman gives birth is not a single decision, but is the outcome of a series of related decisions that make up the "fertility decision tree" (Levine, 2002) including choices surrounding conception and contraception and whether or not to abort a pregnancy. Levine (2002, p. 1) argues that "consistent findings [from different stages of this decision tree] provide stronger evidence of a causal link [from policy to fertility] than focusing on just one stage." Finally, therefore, we present additional supporting evidence from another stage of the fertility tree - use of contraception.

The 1998 and 2002 UK General Household Surveys contained modules on contraception use. We define a binary variable equal to one if the woman reports that she is currently not using contraception either because she is already pregnant or because she wants to get pregnant. We estimate a linear probability model using the same basic difference-in-difference specification (1).

The results are reported in Table 6. They are fully consistent with the findings for births. There was an increase in the proportion of women in the treatment group reporting that they were not using contraception because they were trying to get - or already were - pregnant. This increase is statistically significant at the $10 \%$ level. Further analysis by the number of births the woman has already had (column (2)), shows that, as with actual births, the increases were greatest for women who had previously had no and two births, although as before the differences between the effects are not statistically significant. 


\section{Table 6: Linear model, contraceptive use}

Sample: Women in couples aged 20-45, 1998, 2002

Dependent variable: Not using contraception because pregnant or wanting to get pregnant (0/1)

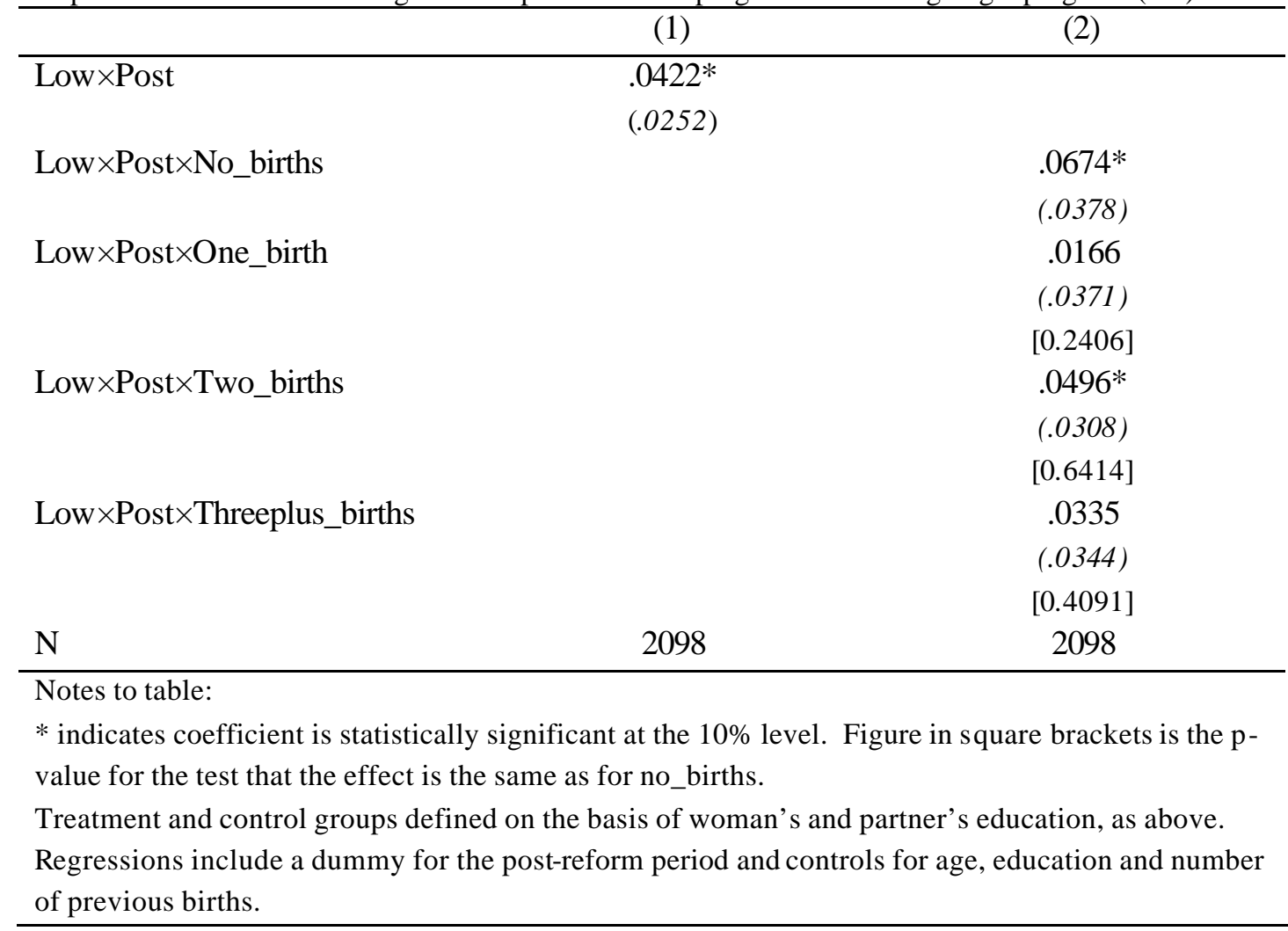

Timing or quantity effects?

At least some of the increase in births after the reforms may reflect women beginning childbearing earlier. In order to shed some light on this, we look at the age at which women had their first birth. Regression results are reported in Table 7. The simple difference-in-difference specification indicates an increase in age at first birth, statistically significant at the 10 per cent level. Including differential trends, the estimated treatment effect is negative, but statistically insignificant. ${ }^{23}$

\footnotetext{
${ }^{23}$ Adding a differential quadratic trend has little effect.
} 
However, looking at (conditional) means may not be appropriate when the shape of the distribution of age at first birth for the low education group has changed over the period to being bi-modal (see Figure 6). We therefore also try estimating a $25^{\text {th }}$ quantile regression (column (3)) which shows a fairly big, although statistically insignificant, decline in age at first birth. Taken together, these results suggest that the reforms may have had an effect in bringing forward births among younger mothers in the treatment group.

Table 7: Linear model, age at first birth

Sample: Women in couples aged 20-45, 1990-2003, first birth in previous 12 months

\begin{tabular}{|c|c|c|c|}
\hline & $\begin{array}{c}(1) \\
\text { OLS }\end{array}$ & $\begin{array}{c}(2) \\
\text { OLS }\end{array}$ & $\begin{array}{l}(3) \\
25^{\text {th }} \text { quantile } \\
\text { regression }\end{array}$ \\
\hline Low $\times$ Post & $\begin{array}{l}.7424^{*} \\
(.5517)\end{array}$ & $\begin{array}{l}-.6807 \\
(.8407)\end{array}$ & $\begin{array}{l}-1.3529 \\
(1.0966)\end{array}$ \\
\hline $\begin{array}{l}\text { Differential Trends } \\
\mathrm{N}\end{array}$ & $\begin{array}{c}\text { None } \\
1349\end{array}$ & $\begin{array}{c}\text { Linear } \\
1349\end{array}$ & $\begin{array}{c}\text { Linear } \\
1349\end{array}$ \\
\hline \multicolumn{4}{|c|}{$\begin{array}{l}\text { Notes to table: } \\
\text { * indicates coefficient is statistically significant at the } 10 \% \text { level. } \\
\text { Regressions include a dummy for the post-reform period and controls for education, region and } \\
\text { housing tenure. }\end{array}$} \\
\hline
\end{tabular}




\section{Figure 6}

Distribution of age at first birth, by education

Women in couples

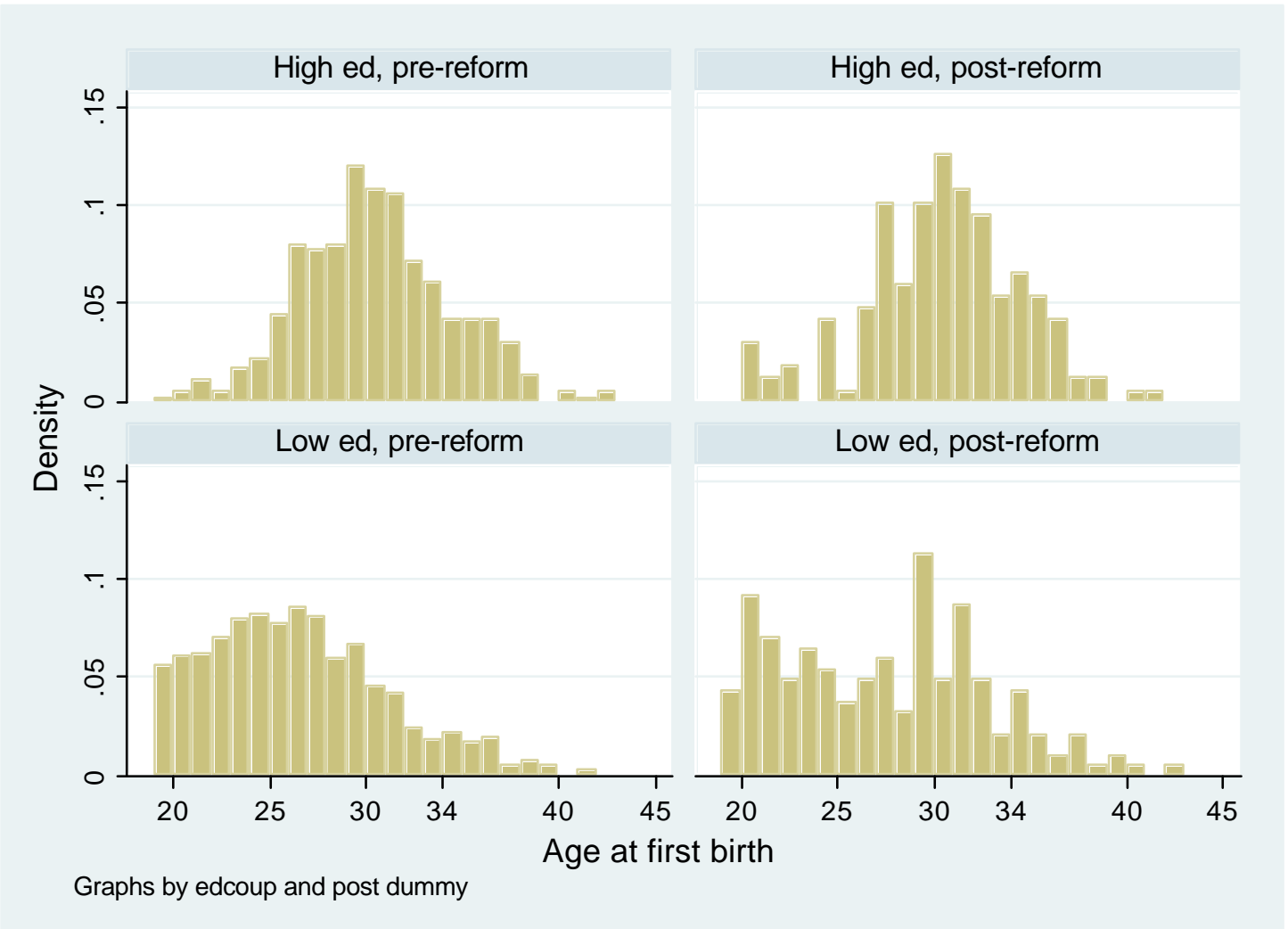

\section{$8 \quad$ Discussion and conclusions}

The reforms that took place in the UK in 1999 make an excellent case study for addressing the question of whether fertility responds to financial incentives, not least because of the scale of the increases. Examining evidence on the response to these reforms, this paper makes a number of contributions to the existing literature on the effect of welfare on fertility.

First, we have shown that more generous government support coincided with an increase in births among the group most affected by the reforms. This increase cannot 
be explained by differential trends or by macro factors. We have also provided supporting evidence of a decline in use of contraception among the group affected.

Our results indicate a sizeable response in childbearing among the group affected by the reform. The probability of having a birth increased by 1.3 percentage points among the low education group, equivalent to a 15 per cent increase. This equates to nearly 45,000 additional births (compared to annual births of 670,000), although some of this may be a change in the timing of births rather than in the quantity.

How does this compare with previous estimates? Milligan (2005) estimated that the probability of birth increased by $17 \%$ for a $\$$ Can 1,000 increase in total support via the Allowance for Newborn Children; in the UK, the increase in annual benefits for the low-education group was around twice this level - potentially for each year of the child's life (see Table 2). Our estimated effect is considerably smaller than this Canadian study. We do not directly estimate an elasticity, but since entitlement to benefits increased by 46 per cent among the low-education group, the implied elasticity is around 0.28. This is greater than Baughman and Dickert-Conlin found for EITC in the US, but within the range estimated by Whittington et al, 1990, and Whittington, 1992. We therefore believe our estimate of the effect to be plausible. Second, we have shown that examining the fertility effects of welfare reform must take account of potential differences across women. In-work tax credits such as WFTC and EITC have potentially ambiguous effects because they may raise the opportunity cost of having children. We argue that the pro-fertility effect is likely to be stronger for women in couples, and provide evidence to support this, consistent with earlier findings from the US.

Finally, we have added some support to the growing evidence that effects vary by 
birth order, and are typically stronger for first births than for subsequent births. One implication of this is that the reforms had an effect on the fertility decisions of households who were not (yet) receiving the benefits. However, McKay, 2000 and 2001, shows that there was a fairly high level of awareness of the new benefits even among those who were not receiving it, which may have come about as a result of the extensive television advertising and/or through word-of- mouth. ${ }^{24}$

\section{References}

Anderberg, Dan. 2008. "Tax credits, income support, and partnership decisions", International Tax and Public Finance, 15(4) pp. 499-526

Angrist, Joshua D, and Alan B. Krueger. 1999. "Empirical strategies in Economics." In Handbook of Economics. Vol. 3, ed. Orley Ashenfelter and David Card, 1277 - 1365. Amsterdam: Else vier Science.

Ashenfelter, Orley C. 1978. "Estimating the effect of training programs on earnings." Review of Economics and Statistics, 60 (February): 47-57.

Becker, Gary S. 1991. A Treatise on the Family (Enlarged Edition). Cambridge: Harvard University Press.

Baughman, Reagan, and Stacy Dickert-Conlin. 2003. "Did Expanding the EITC Promote Motherhood?" American Economic Review Papers and Proceedings, 93(2): 247-250.

Besley, Tim, and Anne Case. 2000 "Unnatural experiments? Estimating the incidence of endogenous policies.” Economic Journal, 110 (November): F672-F694

\footnotetext{
${ }^{24}$ More than one-third of low/moderate-income couples were aware of WFTC although they had never received it
} 
Blundell, Richard, Mike Brewer, and Andrew Shepard. 2005. "Evaluating the labour market impact of the Working Families' Tax Credit using difference in differences." HM Revenue and Customs Working Paper 4.

Blundell, Richard, Alan Duncan, Julian C. McCrae, and Costas Meghir. 2000. "The labour market impact of the Working Family Tax Credit." Fiscal Studies, 21(1): 75-103.

Brewer, Mike, and James Browne. 2006. "The effect of the working families' tax credit on labour market participation." IFS Briefing Note 69.

Brewer, Mike, Alan Duncan, Andrew Shephard, and Maria J. Suarez. 2006. "Did working families' tax credit work? The impact of in-work support on labour supply in Great Britain.”' Labour Economics, 13(6): 699-720.

Dickert-Conlin, Stacy and Chandra, Amitabh (1999). "Taxes and the Timing of Births", Journal of Political Economy, 107(1): 161-177.

Eissa, Nada, and Jeffery B. Liebman. 1996. "Labour Supply Response to the Earned Income Tax Credit." Quarterly Journal of Economics, 111(2): 605-637.

Eissa, Nada and Hilary W. Hoynes. 2004. "Taxes and the market participation of married couples: the earned income tax credit." Journal of Public Economics, 88(9-10): 1931-1958.

Ellwood, David T. 2000. "The Impact of the Earned Income Tax Credit and Social Policy Reforms on Work, Marriage, and Living Arrangements.” National Tax Journal, 53(4): 1063-1106.

Ermisch, John. 1988. "Econometric analysis of birth rate dynamics in Britain." Journal of Human Resources, 23(4): 563-576.

Francesconi, Marco and Wilbert van der Klaauw. 2007. "The socioeconomic consequences of in-work benefit reform for British lone mothers." Journal of Human Resources, 42 (1): 1-31.

Fraser, Clive D. 2001. "Income Risk, the Tax-benefit Sys tem and the Demand for Children.” Economica 68(269): 105-125.

Gans, Joshua. and Leigh, Andrew. (2006), "Born on the First of July: An (Un)Natural Experiment in Birth Timing”, Australian National University DP 529, 
Canberra: Australian National University.

Gregg, Paul, and Susan Harkness. 2003. "Welfare Reform and Lone Parents Employment in the UK." CMPO Working Paper Series 03/072.

Gregg, Paul, Harkness, Susan, and Sarah Smith. 2009. "Welfare reform and lone parents” Economic Journal (forthcoming)

Hills, John, and Jane Waldfogel. 2004. “A 'Third Way' in Welfare Reform: What Are the Lessons for the US?" Journal of Policy Analysis and Management 23(4): 765-788.

Hoynes, Hilary. 1997. "Does welfare play any role in female headship decisions?" Journal of Public Economics 65(1997): 89-118.

Kureishi, Watary. and Wakabayahi, Midori. (2008), “Taxing the Stork”, National Tax Journal, 61(2), 167-188.

Laroque, Guy, and Bernard Salanie. 2005. "Fertility and Financial Incentives in France." CESifo Economic Studies, 50(3): 423-450.

Laroque, Guy, and Bernard Salanie. 2008. 'Does Fertility Respond to Financial Incentives?" CESifo Working Paper 2339.

Leigh, Andrew. 2007. "Earned Income Tax Credits and Supply: Evidence from a British Natural Experiment.” National Tax Journal 60 (2): 205-224.

Levine, Phillip B. (2002) The Impact of Social Policy and Economic Activity Throughout the Fertility Decision Tree. National Bureau of Economic Research working paper 9021

McKay, Stephen. 2000. "Low/moderate-income families in Britain: Work, Working Families' Tax Credit and Childcare in 2000." Department for Work and Pensions Research Report 161

McKay, Stephen. 2001. 'Working Families' Tax Credit in 2001.” Department for Work and Pensions Research Report 205

Milligan, Kevin. 2005. "Subsidizing the Stork: New Evidence on Tax Incentives and Fertility." Review of Economics and Statistics, 87(3): 539-555.

Moffitt, Robert. 1998. "The effect of welfare on marriage and fertility." in Welfare, 
the Family and Reproductive Behaviour: Research Perspectives, ed. Robert Moffitt, 50-97. Washington DC: National Academy Press.

Murphy, Mike, and Anne Berrington. 1993. "Constructing period parity progression ratios from household survey data." in New perspectives on fertility in Britain, ed.Maire N. Bhrolchain, 17-32. London: HMSO

Ohinato, Asako. 2008. Fertility response to financial incentives: Evidence from the Working Families Tax Credit in the UK, The Warwick Economics Research Paper Series (TWERPS), No. 851

Smith, Sarah, and Anita Ratcliffe. 2008. “Women's education and childbearing: A growing divide." Forthcoming in Coase, E., Kneale, D. and Stillwell, J., Understanding Population Trends and Processes: Fertility, children and living arrangements, Basingstoke: Palgrave Macmillan

Whittington, Leslie A., James Alm, and H. Elizabeth Peters. 1990. "Fertility and the personal exemption: implicit pronatalist policy in the United States.” American Economic Review, 80(3): 545-556

Whittington, Leslie, A. 1992. "Taxes and the Family: The Impact of the Tax Exemption for Dependents on Marital Fertility”. Demography, 29(2): 215-226 
Table A1

Summary sample statistics

\begin{tabular}{lcc}
\hline & All women sample & $\begin{array}{c}\text { Women in couples } \\
\text { sample }\end{array}$ \\
\hline Mean age & 32.00 & 33.26 \\
Proportion in a couple & 0.647 & 1.00 \\
Proportion with birth in previous 12 months & 0.066 & 0.086 \\
Mean number of children & 1.22 & 1.48 \\
Left school at minimum school leaving age & 0.662 & 0.715 \\
Left full-time education aged 19+ & 0.338 & 0.285 \\
No. observations - total & 101,330 & 45,024 \\
$1990 / 01$ & 2,293 & 1,115 \\
$1991 / 02$ & 2,432 & 1,203 \\
$1992 / 03$ & 2,434 & 1,138 \\
$1993 / 04$ & 2,334 & 1,064 \\
$1994 / 05$ & 2,363 & 1,065 \\
$1995 / 06$ & 10,470 & 4,771 \\
$1996 / 07$ & 10,267 & 4,637 \\
$1997 / 08$ & 9,386 & 4,256 \\
$1998 / 09$ & 9,219 & 4,060 \\
$1999 / 00$ & 9,895 & 4,294 \\
$2000 / 01$ & 9,410 & 4,064 \\
$2001 / 02$ & 10,715 & 4,655 \\
$2002 / 03$ & 11,020 & 4,760 \\
$2003 / 04$ & 11,486 & 4,931 \\
\hline
\end{tabular}




\section{Table A2}

\section{Regression results, linear probability model}

Sample: Women in couples aged 20-45, 1990-2003

Dependent variable: Birth in the last twelve months $(0 / 1)$

\begin{tabular}{|c|c|c|c|c|}
\hline & Coefficient & $S E$ & Coefficient & $S E$ \\
\hline Low $\times$ Post & 0.0133 & 0.0064 & 0.0158 & 0.0101 \\
\hline Age $\times$ High & -0.0627 & 0.0406 & -0.0669 & 0.0421 \\
\hline Age $\times$ Low & 0.0351 & 0.0276 & 0.0316 & 0.0290 \\
\hline Age $\times 1$ child $\times$ High & 0.2119 & 0.0928 & 0.2010 & 0.0961 \\
\hline Age $\times 2$ children $\times$ High & 0.1524 & 0.1113 & 0.1240 & 0.1153 \\
\hline Age $\times 3+$ children $\times$ High & -0.0265 & 0.2272 & -0.0381 & 0.2350 \\
\hline Age $\times 1$ child $\times$ Low & 0.0565 & 0.0410 & 0.0814 & 0.0433 \\
\hline Age $\times 2$ children $\times$ Low & -0.0229 & 0.0443 & -0.0123 & 0.0466 \\
\hline Age $\times 3+$ children $\times$ Low & -0.0570 & 0.0648 & -0.0470 & 0.0682 \\
\hline $\operatorname{Age}^{2} \times$ High & 0.0343 & 0.0131 & 0.0357 & 0.0136 \\
\hline $\operatorname{Age}^{2} \times$ Low & -0.0130 & 0.0089 & -0.0125 & 0.0093 \\
\hline $\mathrm{Age}^{2} \times 1$ child $\times$ High & -0.0703 & 0.0283 & -0.0659 & 0.0293 \\
\hline $\mathrm{Age}^{2} \times 2$ children $\times$ High & -0.0655 & 0.0323 & -0.0581 & 0.0335 \\
\hline $\mathrm{Age}^{2} \times 3+$ children $\times$ High & -0.0128 & 0.0635 & -0.0104 & 0.0656 \\
\hline $\operatorname{Age}^{2} \times 1$ child $\times$ Low & -0.0196 & 0.0130 & -0.0263 & 0.0137 \\
\hline $\operatorname{Age}^{2} \times 2$ children $\times$ Low & 0.0044 & 0.0138 & 0.0019 & 0.0145 \\
\hline $\mathrm{Age}^{2} \times 3+$ children $\times$ Low & 0.0160 & 0.0197 & 0.0135 & 0.0207 \\
\hline $\mathrm{Age}^{3} \times$ High & -0.0049 & 0.0014 & -0.0051 & 0.0014 \\
\hline $\mathrm{Age}^{3} \times$ Low & 0.0012 & 0.0009 & 0.0012 & 0.0010 \\
\hline $\mathrm{Age}^{3} \times 1$ child $\times$ High & 0.0074 & 0.0028 & 0.0069 & 0.0029 \\
\hline $\mathrm{Age}^{3} \times 2$ children $\times$ High & 0.0081 & 0.0031 & 0.0075 & 0.0032 \\
\hline Age $^{3} \times 3+$ children $\times$ High & 0.0032 & 0.0059 & 0.0030 & 0.0061 \\
\hline $\operatorname{Age}^{3} \times 1$ child $\times$ Low & 0.0022 & 0.0013 & 0.0028 & 0.0014 \\
\hline Age $^{3} \times 2$ children $\times$ Low & -0.0001 & 0.0014 & 0.0001 & 0.0015 \\
\hline Age $^{3} \times 3+$ children $\times$ Low & -0.0013 & 0.0020 & -0.0011 & 0.0021 \\
\hline 1child $\times$ High & -1.9572 & 0.9982 & -1.8798 & 1.0336 \\
\hline 1child $\times$ Low & -0.5295 & 0.4171 & -0.8238 & 0.4415 \\
\hline 2children $\times$ High & -0.9229 & 1.2679 & -0.5715 & 1.3117 \\
\hline 2children $\times$ Low & 0.2100 & 0.4634 & 0.0753 & 0.4878 \\
\hline $3+$ children $\times$ High & 1.0056 & 2.6876 & 1.1701 & 2.7779 \\
\hline $3+$ children $\times$ Low & 0.5246 & 0.7002 & 0.3973 & 0.7373 \\
\hline 1child, youngestage_23 & 0.1480 & 0.0085 & 0.1429 & 0.0090 \\
\hline 1 child, youngestage_45 & 0.0645 & 0.0110 & 0.0630 & 0.0116 \\
\hline 1child, youngestage_67 & -0.0119 & 0.0123 & -0.0152 & 0.0128 \\
\hline 1child, youngestage_89 & -0.0192 & 0.0141 & -0.0213 & 0.0146 \\
\hline 1child, youngestage_10o & -0.0264 & 0.0111 & -0.0280 & 0.0115 \\
\hline 2children, youngestage_23 & 0.0347 & 0.0079 & 0.0371 & 0.0083 \\
\hline 2children, youngestage_45 & 0.0164 & 0.0087 & 0.0127 & 0.0092 \\
\hline 2children, youngestage_67 & 0.0084 & 0.0094 & 0.0062 & 0.0098 \\
\hline 2children, youngestage_89 & -0.0021 & 0.0100 & -0.0029 & 0.0105 \\
\hline 2children, youngestage_10o & 0.0005 & 0.0092 & -0.0013 & 0.0096 \\
\hline 3+children, youngest age_23 & 0.0062 & 0.0099 & 0.0103 & 0.0104 \\
\hline 3+children, youngestage_45 & 0.0059 & 0.0110 & 0.0072 & 0.0114 \\
\hline 3+children, youngestage_67 & -0.0205 & 0.0117 & -0.0180 & 0.0122 \\
\hline 3+children, youngestage_89 & -0.0122 & 0.0126 & -0.0092 & 0.0132 \\
\hline 3+children, youngestage_10o & -0.0154 & 0.0128 & -0.0138 & 0.0132 \\
\hline North East & -0.0231 & 0.0081 & -0.0149 & 0.0180 \\
\hline North West & -0.0066 & 0.0063 & -0.0029 & 0.0157 \\
\hline
\end{tabular}


Yorkshire \& Humberside

East Midlands

West Midlands

East

South East

South West

Wales

Scotland

Northern Ireland

Social housing

Private renter

Other housing tenure

Low education

Post reform period

Lag $\ln$ real house prices

Lag $\ln$ real house prices $\times$ Low

Lag female hourly wage

Lag male hourly wage

Lag male unemployment rate

Lag male unemp rate $\times$ Low

Lag female unemployment rate

Lag female unemp rate $\times$ Low

Constant

$\mathrm{N}$

$\begin{array}{rlrl}-0.0096 & 0.0062 & -0.0045 & 0.0159 \\ -0.0099 & 0.0065 & -0.0057 & 0.0156 \\ -0.0081 & 0.0062 & -0.0057 & 0.0130 \\ -0.0036 & 0.0068 & -0.0062 & 0.0120 \\ -0.0034 & 0.0061 & -0.0112 & 0.0102 \\ -0.0072 & 0.0064 & -0.0088 & 0.0129 \\ -0.0050 & 0.0075 & 0.0016 & 0.0166 \\ -0.0125 & 0.0061 & -0.0068 & 0.0160 \\ -0.0022 & 0.0111 & 0.0057 & 0.0203 \\ 0.0220 & 0.0037 & 0.0205 & 0.0039 \\ -0.0183 & 0.0050 & -0.0201 & 0.0052 \\ 0.0137 & 0.0189 & 0.0220 & 0.0209 \\ -0.3534 & 0.4947 & -0.6355 & 0.5357 \\ -0.0099 & 0.0054 & -0.0181 & 0.0115 \\ & & 0.0010 & 0.0214 \\ & & 0.0252 & 0.0131 \\ & & -0.0175 & 0.0131 \\ & & 0.0163 & 0.0110 \\ & & -0.0160 & 0.3336 \\ & & 0.0683 & 0.3646 \\ & & -0.6570 & 0.7687 \\ & & 0.5942 & 0.8202 \\ 0.2948 & 0.4104 & 0.3012 & 0.5012 \\ & & 40465 & \\ & & & \end{array}$

